\title{
Prevalence of maxillofacial injuries in women who have experienced physical violence reported at a House of Justice in the metropolitan area of Bucaramanga (Colombia)
}

\author{
Prevalencia de lesiones maxilofaciales en mujeres que han sufrido \\ violencia física reportada en una Casa de Justicia del área metropolitana \\ de Bucaramanga (Colombia)
}

Ingrid Johanna Contreras ${ }^{1}$, EdNa Mariam Portillo², Martha Juliana Rodríguez ${ }^{3}$

DDS, Universidad Santo Tom s. Email address: ingi0508@hotmail.com

DDS, Universidad Santo Tom s. Email address: edmariam_25@hotmail.com

Professor, Universidad Santo Tom s. Master in Epidemiology, Universidad Industrial de Santander. Specialist in Pediatric Dentistry and Preventive Orthodontics, Universidad CES. Email address: marthajuro@ustabuca.edu.co

\begin{abstract}
Keywords:
prevalence,

domestic violence,

violence against

women, edema,

hematoma

Abstract

Introduction: the data on physical violence against women in Colombia are high, with the face being one of the most affected regions; however, data on injuries types is limited. The aim of this study was to determine the prevalence of maxillofacial lesions caused by physical violence in women who have reported such violence at a House of Justice in the metropolitan area of Bucaramanga (Colombia) from September 2013 to March 2015. Methods: a descriptive prevalence study was conducted in 258 expert reports filed on the aforementioned dates. Sociodemographic variables, lesion types and aggressor characteristics were analyzed; data was collected through an instrument created based on the parameters of the National Institute for Legal Medicine and Forensic Sciences. Frequencies and proportions were calculated for qualitative variables, as well as measures of central tendency and dispersion for quantitative variables. The Chi ${ }^{2}$ test or Fisher's Exact test were used for bivariate analysis as needed. A $p$ value lower than 0.05 was considered statistically significant. Results: the women/men ratio was 2.8. The prevalence of maxillofacial injuries was $55.4 \%$ when considering 157 expert reports of women 18 years of age or older. In 81 reports (93.1\%) the aggressor was known and in 47 cases (58\%) the aggressor was the husband. Conclusions: the prevalence of maxillofacial injuries was $55.4 \%$, with hematoma being the most common type of injuries as related in 49 reports $(56.3 \%)$.
\end{abstract}

\begin{abstract}
Resumen
Introducci n: en Colombia, las cifras sobre violencia f sica en mujeres son altas, y la cara es una de las regiones $\mathrm{m}$ s afectadas; sin embargo, la informaci $\mathrm{n}$ sobre el tipo de lesiones es limitada. El objetivo de este estudio consisti en determinar la prevalencia de las lesiones maxilofaciales ocasionadas por violencia $\mathrm{f}$ sica en mujeres que lo han denunciado en una Casa de Justicia del rea metropolitana de Bucaramanga (Colombia) desde septiembre de 2013 a marzo de 2015. M todos: se realiz un estudio descriptivo de prevalencia con 258 informes periciales diligenciados en las fechas mencionadas. Se analizaron variables sociodemogr ficas y caracter sticas de las lesiones y del agresor; los datos se recolectaron a trav $\mathrm{s}$ de un instrumento creado con base en los par metros del Instituto Nacional de Medicina Legal y Ciencias Forenses. Se calcularon frecuencias y proporciones para las variables cualitativas, y medidas de tendencia central y dispersi $\mathrm{n}$ para las cuantitativas. Para el an lisis bivariado, se utiliz la prueba $\mathrm{Chi}^{2} \mathrm{o}$ la prueba exacta de Fisher seg $\mathrm{n}$ fuera apropiado. Un valor de $p<0,05$ fue considerado como estad sticamente significativo. Resultados: la raz n de feminidad fue de 2,8 mujeres por cada hombre. La prevalencia de lesiones maxilofaciales fue del 55,4\% al tener en cuenta 157 informes periciales de mujeres de 18 a os o mayores. En 81 (93,1\%) informes, el agresor fue conocido y en 47 (58\%) fue el esposo. Conclusiones: la prevalencia de lesiones maxilofaciales fue del $55,4 \%$, siendo el hematoma el tipo de lesi n m s frecuente al estar registrado en 49 (56,3\%) informes.
\end{abstract}

Palabras clave: prevalencia, violencia dom stica, violencia contra la mujer, edema, hematoma

Submitted: April 20/2019 - accepted: June 13/2019

How to quote this article: Contreras IJ, Portillo EM, Rodr guez MJ. Prevalence of maxillofacial injuries in women who have experienced physical violence reported at a Justice House in the metropolitan area of Bucaramanga (Colombia). Rev Fac Odontol Univ Antioq. 2019; 31(1-2): 102-111. DOI: http:// dx.doi.org/10.17533/udea.rfo.v31n1-2a9 


\section{INTRODUCTION}

Violence affects human beings physically and emotionally. Violence against women, either intimate partner violence or sexual violence, is a serious public health problem and a violation of women's human rights. ${ }^{1}$ Violence against women has increased globally or rather has gained more public attention. Recently the United Nations (UN) reports that since 1995 more than 100 countries have shown interest in violence against women; between 1995 and 2014, more than 40 nations conducted surveys and initiated programs against this problem. ${ }^{2}$ In consequence, various strategies have increased the number of reports in relation to violence and its manifestations, such as physical, psychological, sexual, economic, domestic, and work violence. ${ }^{3}$

The literature reports a higher frequency of violence against women than against men; a multicenter study conducted in some provinces in ten countries found a lifethreatening prevalence of physical violence against women by their partners, ranging from $13 \%$ (Japan) to $61 \%$ (Peru). ${ }^{1}$

In Colombia, Act 1257 of 2008 defines violence against women as "any action or omission that causes death or physical, sexual, psychological, economic or patrimonial harm in her condition as woman, as well as threats of such acts, coercion or arbitrary deprivation of liberty, whether in public or private settings". ${ }^{4}$

Today, several Colombian state institutions, such as houses of justice, prosecutors' offices, courts, family emergency services and police inspections work hard to break the fear and silence of victims, since reporting allows a better attention to victims. These institutions not only protect women but also children, youths, the elderly and men who experience some form of violence. ${ }^{5}$

In this regard, the 2015 National Demographic and Health Survey (Encuesta Nacional de Demografa y Salud, ENDS) found that $31.9 \%$ of women in Colombia had once experienced physical violence by their partners, with "shaking" and hand blows being the most frequent forms of aggression. ${ }^{6}$ Despite various awareness-raising campaigns, the number of injuries from violent causes remains high; data issued by the National Institute of Legal Medicine and Forensic Sciences show that of the 50,072 reports filed in 2017 in cases of intimate partner violence, $43,176(86.2 \%)$ affected women. ${ }^{7}$

A work done by Mafla et al in 2015 in the city of Pasto (Colombia) found that $49.9 \%$ of maxillofacial injuries were due to violence, but the study did not specify whether the victims were men or women, or the most frequent type of injury. ${ }^{8}$

Nelms et al (2009) highlighted the importance of health professionals recognizing, reporting and addressing domestic violence injuries against women. In addition, they suggest that health schools should include information on how to recognize these attacks, how to conduct anamnesis so that women feel comfortable reporting, and how to offer support in this situation. ${ }^{9}$ The aim of the present study was to determine the prevalence of maxillofacial injuries caused by physical violence in women who have reported such violence at a House of Justice in the metropolitan area of Bucaramanga (Colombia) from September 2013 to March 2015. 


\section{METHODS}

Adescriptiveprevalencestudywasconducted in 258 expert reports that represented the total number of complaints made at a House of Justice in the Bucaramanga metropolitan area from September 2013 to March 2015. To this end, data was collected from expert reports of women 18 years of age or older, which were fully filled out. The output variable was the presence of maxillofacial injuries, and the explanatory variables were either sociodemographic (age, socioeconomic stratum, schooling level, place of origin, occupation, health insurance coverage), related to the physical injury (month of aggression, year, visible marks, classification, number and anatomical place of injury) or related to the aggressor (sex, kinship).

A data collection tool was designed based on the Technical Regulations for the Comprehensive Management of Injuries in Forensic Clinic of the National Institute for Legal Medicine and Forensic Sciences. ${ }^{10} \mathrm{~A}$ pilot study was conducted in 114 expert reports in order to adjust the variables in the tool, estimate the time to review each report and define the logistics of the study.

Permission to enter, work and review expert reports at a House of Justice in the metropolitan area of Bucaramanga (Colombia) was requested. The metropolitan area of Bucaramanga is in northeast Colombia and comprises four municipalities with nearly $1,133,000$ inhabitants.

The documentary work relied on the support of a legal physician affiliated to the House of Justice; data was collected jointly by two researchers (IJC and EMP) who filled out all the forms. If any data was missing, the legal physician helped search the system to find the missing information and record it.
The data was digitized in duplicate in two Excel databases; these databases were validated with the Epidata 3.1 software and all errors were corrected until a fully refined database was obtained. It was finally exported to the Stata I/C version 12 statistical package.

Age groups were formed as follows: 15 to 24 years, 25 to 34 years, 35 to 44 years, 45 to 54 years, 55 to 64 years and 65 years or older. The months when injuries happened were also grouped in quarters (first quarter: January to March, second quarter: April to June, third quarter: July to September, fourth quarter: October to December).

The univariate analysis was performed according to the nature and distribution of the variables by calculating central tendency and dispersion measures for quantitative variables, and frequencies and proportions for the qualitative ones. The bivariate analysis included some variables for the group of women with no maxillofacial injuries and those who did have them. The $\mathrm{Chi}^{2}$ test or Fisher's Exact test were used as needed. A $p$ value lower than 0.05 was considered statistically significant.

\section{Ethical considerations}

According to Resolution 008430 of 1993 of the Republic of Colombia's Ministry of Health, this study was classified as a "risk-free investigation". ${ }^{11}$ At all times, the identity of people who reported the cases of violence at the House of Justice was respected and protected to ensure their privacy and personal integrity. The ethical principles of autonomy, justice, beneficence and nonmalice were fully fulfilled. In addition, the study was approved by the Ethics Committee of the Universidad Santo Tom s' School of Dentistry (Minutes 1/2017 CI-ODUSTA). 


\section{RESULTS}

A total of 258 expert reports were reviewed, with $190(73.6 \%)$ corresponding to women; the women/man ratio was 2.8 . The average age of people who reported physical violence was $28.8 \pm 14.2$ years [ $95 \% \mathrm{Cl} 27.1$ 30.6] ranging from 1 to 81 years (median = 26.5 years).

Fifty-three (20.5\%) people were under the age of 18 , and $33(62.3 \%)$ of these were women. The average age of children was $11.6 \pm 4.5$ years [95\% Cl 10.3-12.8] (median $=12$ ). Of the 157 women of legal age, 87 (55.4\%) had injuries in the maxillofacial region as victims of physical violence (Figure 1).

\section{Overview of legal adult women who reported physical violence}

The average age of the 157 women was $32.9 \pm 12.6$ years $[95 \% \mathrm{Cl} \quad 30.9-34.9]$ ranging from 19 to 81 years (median $=30$ ). Table 1 shows the distribution of some of the sociodemographic characteristics in the population of women who experienced physical violence with and without maxillofacial injuries.

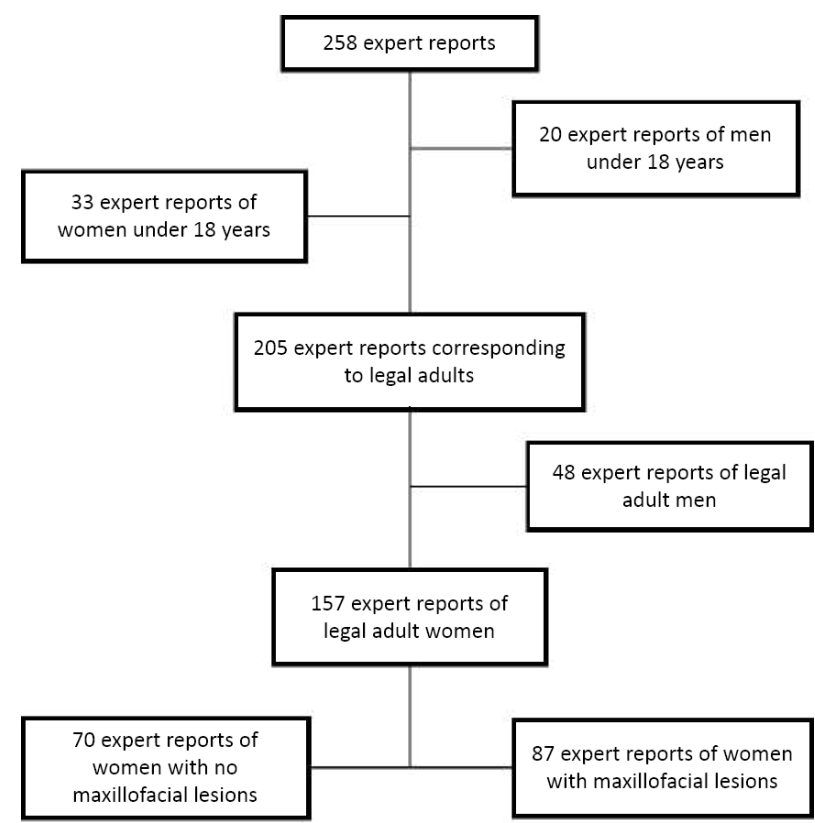

Figure 1. Flowchart of expert reports filed at a House of Justice in the metropolitan area of Bucaramanga, Colombia (September 2013-March 2015)

Source: by the authors

Table 1. Sociodemographic characteristics of women who experienced physical violence and whose expert report was filed at a Justice House in the metropolitan area of Bucaramanga, Colombia (September 2013-March 2015) $(n=157)$

\begin{tabular}{|c|c|c|c|c|}
\hline Variable & $\begin{array}{l}\text { Global } \\
\text { n (\%) }\end{array}$ & $\begin{array}{l}\text { No maxillofacial injuries } \\
\qquad n(\%)\end{array}$ & $\begin{array}{l}\text { With maxillofacial injuries } \\
\qquad \mathbf{n}(\%)\end{array}$ & $P$ \\
\hline Age group (years) & & & & 0.894 \\
\hline $18-24$ & $52(33.1)$ & $20(28.6)$ & $32(36.8)$ & \\
\hline $25-34$ & $47(29.9)$ & $22(31.4)$ & $25(28.7)$ & \\
\hline $35-44$ & $33(21.0)$ & $17(24.3)$ & $16(18.4)$ & \\
\hline $45-54$ & $15(9.6)$ & $7(10.0)$ & $8(9.2)$ & \\
\hline $55-64$ & $5(3.2)$ & $2(2.9)$ & $3(3.5)$ & \\
\hline$\geq 65$ & $5(3.2)$ & $2(2.9)$ & $3(3.5)$ & \\
\hline Trimester & & & & $0.789^{a}$ \\
\hline First & $58(36.9)$ & $23(32.9)$ & $35(40.2)$ & \\
\hline Second & $39(24.8)$ & $18(25.7)$ & $21(24.1)$ & \\
\hline Third & $36(22.9)$ & $18(25.7)$ & $18(20.7)$ & \\
\hline Fourth & $24(15.3)$ & $11(15.7)$ & $13(14.9)$ & \\
\hline Visible marks & & & & $0.087^{b}$ \\
\hline No & $3(1.9)$ & $3(4.3)$ & $0(0.0)$ & \\
\hline Yes & $154(98.1)$ & $67(95.7)$ & $87(100.0)$ & \\
\hline
\end{tabular}

a: Chi squared test; b: Fisher's Exact Test. Visible marks: skin signs as evidence of violence

Source: by the authors 


\section{Description of legal adult women who reported maxillofacial injuries}

Of the 157 expert reports showing physical violence in women aged 18 years or older, $87(55.4 \%)$ showed injuries in the maxillofacial region (face, skull or neck). The average age was $32.3 \pm 13.0$ years [95\% $\mathrm{Cl}$ 29.7-35.1], ranging from 19 to 81 years (median $=28$ ). No statistically significant difference was found when comparing the age of the 70 women who did not have maxillofacial injuries with the 87 who did $(p=0.3646)$.

More than half of the reports corresponded to women in socioeconomic stratum 2 (low), $54(62.1 \%)$ had completed high school and $36(41.4 \%)$ were housewives. In addition, in $81(93.1 \%)$ of expert reports the aggressor was known and in $71(81.6 \%)$ was a male (Table 2).

The average number of injuries in the maxillofacial region was $2.3 \pm 1.0$ [95\% IC 2.1-2.5] ranging from one to five injuries (median $=2)$. Forty-seven $(54.0 \%)$ expert reports stated that the affected site was the face, followed by face and skull with 14 reports $(16.1 \%)$. The most common type of lesion was hematoma in 49 (56.3\%) expert reports, and there were facial fractures recorded in 3 reports $(3.5 \%)$. In relating the type of lesion to the anatomical region where they happened, a statistically significant difference was found with respect to the presence of edema $(p<0.001)$ and trauma $(p=0.035)$ (Table 3). It was also noted that in $24(27.6 \%)$ expert reports the eyelids were affected followed by the orbit and the malar bone (Figure 2).
Table 2. Sociodemographic characteristics of women who experienced injuries in the maxillofacial region and whose expert report was recorded at a House of Justice in the metropolitan area of Bucaramanga, Colombia (September 2013-March 2015) ( $\mathrm{n}=87)$

\begin{tabular}{|c|c|}
\hline Variable & n (\%) \\
\hline \multicolumn{2}{|c|}{ Age group (years) } \\
\hline $18-24$ & $32(36.8)$ \\
\hline $25-34$ & $25(28.7)$ \\
\hline $35-44$ & $16(18.4)$ \\
\hline $45-54$ & $8(9.2)$ \\
\hline $55-64$ & $3(3.5)$ \\
\hline$\geq 65$ & $3(3.5)$ \\
\hline \multicolumn{2}{|c|}{ Socioeconomic stratum } \\
\hline 1 & $7(8.1)$ \\
\hline 2 & $50(57.5)$ \\
\hline 3 & $30(34.5)$ \\
\hline \multicolumn{2}{|c|}{ Health insurance } \\
\hline None & $4(4.6)$ \\
\hline Contributory & $36(41.4)$ \\
\hline Subsidized & $47(54.0)$ \\
\hline \multicolumn{2}{|l|}{ School level } \\
\hline Primary & $12(13.8)$ \\
\hline Secondary & $54(62.1)$ \\
\hline Technology & $15(17.2)$ \\
\hline University & $6(6.9)$ \\
\hline \multicolumn{2}{|l|}{ Occupation } \\
\hline None & $3(3.5)$ \\
\hline Housewife & $36(41.4)$ \\
\hline Employee & $27(31.0)$ \\
\hline Independent & $16(18.4)$ \\
\hline Other & $5(5.8)$ \\
\hline \multicolumn{2}{|l|}{ Aggressor } \\
\hline Unknown & $6(6.90)$ \\
\hline Known & $81(93.10)$ \\
\hline \multicolumn{2}{|c|}{ Sex of aggressor } \\
\hline Female & $16(18.4)$ \\
\hline Male & $71(81.6)$ \\
\hline
\end{tabular}

Source: by the authors 
Table 3. Anatomical place and type of lesion recorded in the expert reports of women who reported physical violence at a Justice House in the metropolitan area of Bucaramanga, Colombia (September 2013-March 2015) (n=87)

\begin{tabular}{|c|c|c|c|c|c|c|c|}
\hline \multirow{2}{*}{ Lesion type } & Face & Neck & Skull & Face and neck & Face and skull & Face, neck and skull & \multirow{2}{*}{$P$} \\
\hline & n (\%) & n (\%) & n (\%) & n (\%) & n (\%) & n (\%) & \\
\hline Hematoma & & & & & & & 0,483 \\
\hline No & $18(47.4)$ & $2(5.3)$ & $7(18.4)$ & $4(10.5)$ & $5(13.2)$ & $2(5.3)$ & \\
\hline Yes & $29(59.2)$ & $2(4.1)$ & $7(14.3)$ & $1(2.0)$ & $9(18.4)$ & $1(2.0)$ & \\
\hline Edema & & & & & & & $<0.001$ \\
\hline No & $22(52.4)$ & $4(9.5)$ & $7(16.7)$ & $5(11.9)$ & $1(2.4)$ & $3(7.1)$ & \\
\hline Yes & $25(55.6)$ & $0(0.0)$ & $7(15.6)$ & $0(0.0)$ & $13(28.9)$ & $0(0.0)$ & \\
\hline Laceration & & & & & & & 0.174 \\
\hline No & $31(55.4)$ & $2(3.6)$ & $11(19.6)$ & $4(7.1)$ & $8(14.3)$ & $0(0.0)$ & \\
\hline Yes & $16(51.6)$ & $2(6.5)$ & $3(9.7)$ & $1(3.2)$ & $6(19.4)$ & $3(9.7)$ & \\
\hline Trauma & & & & & & & 0.035 \\
\hline No & $39(58.2)$ & $3(4.5)$ & $12(17.9)$ & $1(1.5)$ & $9(13.4)$ & $3(4.5)$ & \\
\hline Yes & $8(40.0)$ & $1(5.0)$ & $2(10.0)$ & $4(20.0)$ & $5(25.0)$ & $0(0.0)$ & \\
\hline
\end{tabular}

Fisher's Exact Test

Source: by the authors

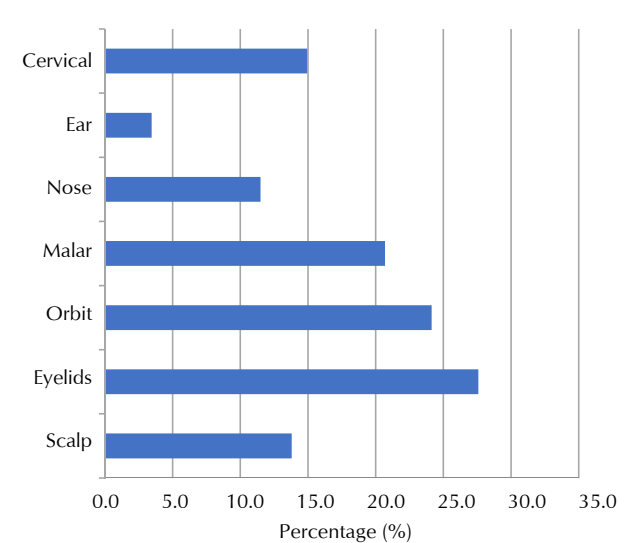

Figure 2. Anatomical location of the maxillofacial region where the injuries happened according to the expert reports of the women who reported physical violence at a House of Justice in the metropolitan area of Bucaramanga, Colombia (September 2013-March 2015).

Source: by the authors

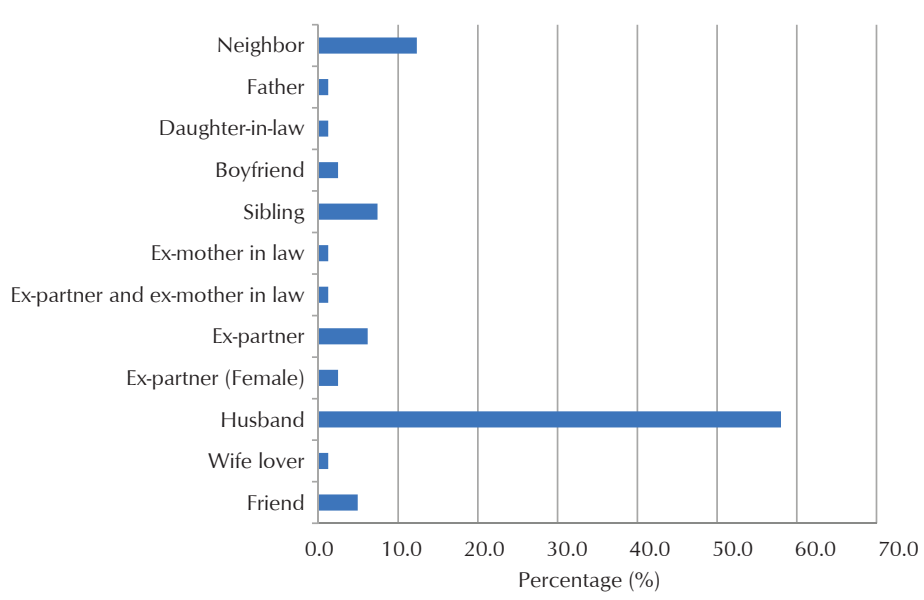

Figure 3. Relationship of the aggressor to the women who reported physical violence and had maxillofacial injuries according to the expert reports reviewed in a House of Justice in the metropolitan area of Bucaramanga, Colombia (September 2013-March 2015)

Source: by the authors

\section{DISCUSSION}

Concerning the aggressor's relationship to the victim, 47 (58\%) expert reports state that the aggressor was the husband, followed by a neighbor or a sibling (Figure 3 ).
The expert reports of women who reported physical violence at a House of Justice in the metropolitan area of Bucaramanga (Colombia) showed a prevalence of maxillofacial lesions (face, skull and neck) of 55.4\% 
[95\% Cl 47.6\% -63.3\%]. This value is similar to that found by other studies that report a prevalence of maxillofacial injuries of $45.8 \%$ and $50.4 \%$ in Brazil and Malaysia, respectively. ${ }^{12,13}$ However, Wong et al showed a prevalence of $77.6 \%$ when reviewing 223 women's records in China during 2010 and $2011 .{ }^{14}$ Le et al also observed a higher prevalence than that found in the present study, as $81.0 \%$ of victims of domestic violence in their study had maxillofacial injuries. ${ }^{15}$

The face was the region affected in a greater proportion (54.0\%). Saddki et al (2010) stated that aggression in this area is very common because it is easily accessible to the aggressor. They also suggest that blows are directed towards this region because it affects the victim's image and reduces the person's self-esteem. ${ }^{13}$ In addition, it can cause permanent physical consequences (scars, difficulty in chewing or swallowing), as well as constant suffering and a deterioration of the victims' quality of life. ${ }^{12,16}$ Some studies agree with these findings and even suggest that injuries in the head, face and neck can be considered markers of domestic violence as a sensitivity of $95 \%$ and a specificity of $45 \%$ has been found. ${ }^{17,18}$

Twenty-five (28.7\%) expert reports recorded a single lesion, with hematoma being the most common. In addition, 3.5\% of women had fractures in the maxillofacial region. While several studies also showed that injuries occurred mostly on soft tissues, there were differences regarding frequency. ${ }^{12-14,19}$

The findings related to injuries to dental structures are consistent with other studies in which such injuries did not occur either. ${ }^{13,20}$ However, Hashemi and Beshkar conducted a study in records of patients who had experienced fractures by domestic violence in Tehran, Iran, reporting that $4.3 \%$ of women had dental fractures. ${ }^{21}$ In Brazil, da Silva et al assessed 223 women victims of violence, finding out that 197 of them had intraoral injuries, with $51 \%$ of these reporting injuries in teeth. ${ }^{22}$

Several studies have found that the most common mechanism for producing maxillofacial injuries is fist blowing; usually, a heavy blow causes the woman to fall to the floor, so that no fractures occur unless the woman is victim of several blows. ${ }^{14,23}$ In the present study, it was not possible to identify the mechanism that caused the lesion since the Protocol for Expert Reporting did not contain this item specifically.

The most common schooling level reported in the expert reports of women with maxillofacial injuries was secondary education by $62.1 \%, 57.5 \%$ showed that the women belonged to a socioeconomic stratum 2 (low), and $41.4 \%$ showed that the occupation of the assaulted women was "housewife". However, by grouping the women who reported being employed with those that are independent workers, it was observed that $49.4 \%$ of them had suffered physical violence, suggesting that the economic situation is not necessarily a trigger of violence, as previously reported. ${ }^{21}$ Tuesca and Borda evaluated the prevalence of marital physical abuse in Colombian women, finding out that the likelihood of abuse increases as incomes fall below 300,000 Colombian pesos (about US\$94). ${ }^{24}$ However, the proportion of assessed women with incomes above 300,000 Colombian pesos was $19.6 \%$.

A very important aspect to consider is the aggressor's kinship to the victim. The information obtained in the present study agrees with several studies that conclude 
that the aggressor is usually the husband or partner of the assaulted woman. ${ }^{13,22,25,26}$

Among the limitations of the present study is the short period evaluated due to the availability of expert reports. In addition, secondary data were used, so it was not possible to analyze aspects other than those included in the reports, such as the geographical location where the aggression occurred, the presence of witnesses, the consumption of alcohol or psychoactive substances, the evolution of injuries, and the mechanisms of aggression. Another aspect to consider is that women often fail to report, and therefore the data on prevalence of physical violence against women may be underestimated.

This study shows a high prevalence of maxillofacial injuries. Also, women/men ratio is very worrying in this evaluation. Violence against women in Colombia is an issue that requires much more attention since the numbers are alarming and not all cases are known. Health personnel should be trained to detect these injuries and provide women victims of violence with the necessary support. In addition, it should be highlighted that injuries are not only physical but also psychological when the victim's right to life is attacked.

\section{ACKNOWLEDGMENTS}

The authors would like to thank Dr. Cielo $\mathrm{D}$ az Amado for her collaboration in data collection and interpretation.

\section{CONFLICTS OF INTEREST}

The authors state that they have no conflict of interest.

\section{CORRESPONDING AUTHOR}

\author{
Martha Juliana Rodr guez \\ Universidad Santo Tom s \\ (+57) 3186514623 \\ marthajuro@ustabuca.edu.co - marthajuro@ \\ gmail.com
}

Carrera 21 No. 36-83 apto. 903

Floridablanca, Colombia

\section{REFERENCES}

1. Garcia-Moreno C, Jansen HA, Ellsberg M, Heise L, Watts CH, Health WHOM-cSoWs et al. Prevalence of intimate partner violence: findings from the WHO multi-country study on women's health and domestic violence. Lancet. 2006; 368(9543): 1260-9. DOI: https://doi.org/10.1016/S0140-6736(06)69523-8

2. Organizaci $\mathrm{n}$ de Naciones Unidas Mujeres. Hechos y cifras: acabar con la violencia contra mujeres y ni as [Internet]. Available in https://www.unwomen.org/es/what-we-do/ending-violence-against-women/ facts-and-figures

3. Krantz G, Garcia-Moreno C. Violence against women. J Epidemiol Community Health. 2005; 59(10): 81821. DOI: https://doi.org/10.1136/jech.2004.022756

4. Rep blica de Colombia. Ley 1257 de 2008. Bogot : Congreso de la Rep blica; 2008.

5. Rep blica de Colombia. Programa nacional casas de justicia: la justicia entra por casa. Bogot : Imprenta Nacional de Colombia; 2012. 
Prevalence of maxillofacial injuries in women who have experienced physical violence reported at a House of Justice in the metropolitan...

6. Ministerio de Salud y Protecci n Social, Profamilia. Violencias de g nero. En: Encuesta nacional de demograf a y salud. Tomo 2. [Bogot ]: Minsalud; 2015. p.395 - 454

7. Instituto Nacional de Medicina Legal y Ciencias Forenses. Comportamiento de la violencia de pareja. En: Forensis: datos para la vida. Bogot : Instituto Nacional de Medicina Legal y Ciencias Forenses; 2018. p.257-300.

8. Mafla AC, L pez EA, Guerrero KA, Rubiano S, Insuasty AC, Bola os EO et al. Estudio retrospectivo de causas de trauma maxilofacial en Pasto, Colombia de 2001 a 2006. Rev Ind Santander Salud. 2009; 41(2): $142-8$.

9. Nelms A, Gutman M, Solomon E, Dewald J, Campbell P. What victims of domestic violence need from dental profession. J Dent Educ. 2009; 73(4): 490-8.

10. Instituto Nacional de Medicina Legal y Ciencias Forenses. Reglamento t cnico para el abordaje integral de lesiones en cl nica forense. Bogot : Imprenta Nacional de Colombia; 2010.

11. Rep blica de Colombia, Ministerio de Salud. Resoluci n No. 08430 de 4 de octubre de 1993. Bogot : Minsalud; 1993.

12. De Macedo Bernardino I, Santos LM, Ferreira AVP, de Almeida Lima TLM, da N brega L, d'Avila S. Intimate partner violence against women, circumstances of aggressions and oral-maxillofacial traumas: a medical-legal and forensic approach. Leg Med (Tokyo). 2018; 31: 1-6. DOI: https://doi.org/10.1016/j. legalmed.2017.12.001

13. Saddki N, Suhaimi AA, Daud R. Maxillofacial injuries associated with intimate partner violence in women. BMC Public Health. 2010; 10: 268. DOI: https://doi.org/10.1186/1471-2458-10-268

14. Wong JY, Choi AW, Fong DY, Wong JK, Lau CL, Kam CW. Patterns, aetiology and risk factors of intimate partner violence-related injuries to head, neck and face in Chinese women. BMC Womens Health. 2014; 14: 6. DOI: https://doi.org/10.1186/1472-6874-14-6

15. Le BT, Dierks EJ, Ueeck BA, Homer LD, Potter BF. Maxillofacial injuries associated with domestic violence. J Oral Maxillofac Surg. 2001; 59(11): 1277-83; discussion 83-4. DOI: https://doi.org/10.1053/ joms.2001.27490

16. Caldas IM, Magalh es $\mathrm{T}$, Afonso A, Matos E. The consequences of orofacial trauma resulting from violence: a study in Porto. Dent Traumatol. 2010; 26(6): 484-9. DOI: https://doi.org/10.1111/j.16009657.2010.00936.x

17. Ochs HA, Neunschwander MC, Dodson TB. Are head, neck and facial injuries markers of domestic violence? J Am Dent Assoc. 1996; 127(6): 757 - 61. DOI: https://doi.org/10.14219/jada.archive.1996.0311

18. Brink O. When violence strikes the head, neck, and face. J Trauma. 2009; 67(1): 147-51. DOI: https://doi. org/10.1097/TA.0b013e318182f77f

19. Da N brega LM, Bernardino IM, Barbosa KGN, E Silva JAL, Massoni A, d'Avila S. Pattern of oral-maxillofacial trauma from violence against women and its associated factors. Dent Traumatol. 2017; 33(3): 181-8. DOI: https://doi.org/10.1111/edt.12327

20. Arosarena OA, Fritsch TA, Hsueh Y, Aynehchi B, Haug R. Maxillofacial injuries and violence against women. Arch Facial Plast Surg. 2009; 11(1): 48-52. DOI: https://doi.org/10.1001/archfacial.2008.507

21. Hashemi HM, Beshkar M. The prevalence of maxillofacial fractures due to domestic violence-a retrospective study in a hospital in Tehran, Iran. Dent Traumatol. 2011; 27(5): 385-8. DOI: https://doi. org/10.1111/j.1600-9657.2011.01016.x 
22. Da Silva EN, Oliveira Matos FRR, Pimienta RMC, Rodrigues JLS, Marques JAM, Musse JdO, et al. Epidemiological profile and characterization of oral and maxillofacial injuries in women victims of interpersonal violence. Int J Odontostomatol. 2016; 10(1): 11-6.

23. Quintana D az JD, Giralt L pez BM. Analisis de las fracturas maxilofaciales en deportes de combate. Rev. cuba. ortop. traumatol. 1998; 12(1-2): 66-8.

24. Tuesca R, Borda M. [Marital violence in Barranquilla [Colombia]: prevalence and risk factors]. Gac Sanit. 2003; 17(4): 302-8.

25. Owusu Adjah ES, Agbemafle I. Determinants of domestic violence against women in Ghana. BMC Public Health. 2016; 16: 368. DOI: https://doi.org/10.1186/s12889-016-3041-x

26. D az FJM, Fern ndez CA. Clinical and epidemiological characteristics of the maxillofacial trauma due to physical violence against the woman. MediSan. 2014; 18(12): 1630-8. 